\title{
PENGUATAN KELEMBAGAAN BUM DESA MENJADI KEKUATAN BARU EKONOMI DI DESA DI DESA WAJAH JAYA DAN DESA MULIA JAYA KABUPATEN BUTON
}

\author{
Anwar Sadat ${ }^{1}$, Mahyudin $^{2}$, Hastuti, $^{3}$ \\ Fakultas Ilmu Sosial dan Ilmu Politik Universitas Muhammadiyah Buton Jl. \\ Betoambari No. 36 Kota Baubau, 93721, Indonesia.
}

Email: anwar.sadat@umbuton.ac.id

\begin{abstract}
Abstrak
Sektor perekonomian Kabupaten Buton didominasi oleh sektor pertanian yang berbasis di pedesaan namun pertumbuhannya sangat lamban. Upaya pemerintah dalam mengentaskan kemiskinan dilakukan dengan memberikan keputusan bagi pemerintah yang berada di desa. Upaya itu tercetus dalam badan yang disebut dengan BUMDES. BUMDES sendiri merupakan badan usaha yang seluruh atau sebagian permodalannya berasal dari desa. Modal yang disisihkan nantinya bisa dimanfaatkan untuk menciptakan lapangan pekerjaan ataupun meningkatkan pelayanan masyarakat yang baik. Faktor penyebab kurang berhasilnya programprogram tersebut paling dominan adalah daya kreativitas dan inovasi masyarakat desa dalam mengelola, dan menjalankan mesin ekonomi di perdesaan. Sistem dan mekanisme kelembagaan ekonomi di pedesaan tidak berjalan efektif sehingga berimplikasi pada Predikat Daerah Tertinggal Bagi Universitas Muhammadiyah Buton, kerjasama dengan BUMDes akan berimplementasi pada lahirnya berbagai jurnal mengenai pengembangan ekonomi pedesaan, menjadi materi bagi program pengabdian pada masyarakat di Desa Wajah Jaya, dan Desa Mulia Jaya Kecamatan Lasalimu Selatan. Peran strategis kampus dengan para akademisinya tentu saja bakal menjadi amunisi yang sangat strategis bagi desa-desa di Kabupaten Buton sehingga bisa menemukan solusi dan rumusan proses yang lebih cepat menuju desa sejahtera. Di sisi lain, wacana ekonomi desa khususnya BUMDes juga bakal mendorong para akademisi mengkaji lebih jauh berbagai potensi ekonomi desa yang hingga hari ini masih butuh banyak dukungan.
\end{abstract}

\section{Kata Kunci: Kelembagaan, Bumdes, Ekonomi}

\section{A. Pendahuluan}

Dalam Program kemitraan masyarakat ini Khalayak sasaran (Mitra) program adalah Masyarakat yang prodiktif secara ekonomi. Mitra sangat berharap 
bekerjasama dengan Perguruan Tinggi untuk melakukan Penguatan kelembagaan Bumdes menjadi Kekuatan Ekonomi Baru Di desa sebagai Mitra di Desa yaitu Desa Wajah Jaya dan Desa Mulia Jaya Kecamatan Lasalimu Selatan menjadi venue bagi kekuata ekonomi desa untuk proses produksi, distribusi, sekaligus pemasaran.

Potensi Desa Wajah Jaya dan Desa Mulia Jaya Kecamatan Lasalimu Selatan Kabupaten Buton Sulawesi Tenggara. Jarak yang ditempuh sekitar 50 kilometer dari arah ibu kota Kabupaten Buton. Brdasarkan Observasi awal Desa Wajah Jaya sejak tahun 2017 sudah ada BUMDes namun belum ada implimentasinya di Desa dan Desa Mulia Jaya belum memilki Badan Usaha Milik Desa (BUMDes) Oleh karena itu, pemerintah daerah dan pemerintah desa dianggap masih perlu untuk membentuk badan usaha di desa dan meningkat tata kelola dan membina BUMDes dengan beberapa hal. Yakni menetapkan mandat dan arah pengembangan yang jelas terhadap BUMDes, membina sinergi BUMDes dengan SKPD terkait dan antar BUMDes dalam RPJMD, menyediakan serta menerapkan regulasi dan kebijakan pemerintah daerah secara memadai dalam pembinaan BUMDes.juga diharapakn segera menyediakan prosedur operasional standar di unit kerja pembina BUMDes terkait tata kelola pembinaan BUMDes, serta melakukan inventarisasi dan identifikasi permasalahan BUMDes secara sistematis serta melakukan tindak lanjut atas identifikasi masalah tersebut.

\section{B. Masalah}

Permasalahan utama yang dihadapi oleh Mitra (I) di Desa Wajah Jaya adalah (1) Minimnya modal sebagai pendanaan usaha. Pada tahun anggaran 2019 termen I dianggarkan Rp. 50.000.000. (lima puluh Juta Rupiah) pada bulan Juni sedangkan termen II Rp. 50.000.000 pada bulan Desember tahun 2019. Dan total keseluruhan penyertaan modal awal Rp. 100.000.000,-. (2) Belum ada struktur Organisasi yang jelas karena salah seorang pengurus Bumdes sudah diangkat menjadi kepala dusun. (3) Belum Jelas Program kerja BUMDes karena belum dituangkan dalam Perde dan RPJM Desa (4) Belum disediakan lahan unutk kantor BUMDes (5) Rencana penguatan kelembagaan ekonomi desa berbasis ekonomi kolaboratif yang belum terarah dengan baik dan belum mampu diakomodir secara 
baik oleh pemerintah. Sedangkan Permasalahan yang dihadapi oleh Mitra (II) Desa Mulia Jaya adalah (1) Desa Mulia Jaya belum memiliki BUMDes sehingga membutuhkan pendampingan dari berbagai pihak baik dari pemerintah, swasta, NGO, Perguruan Tinggi maupun lembaga-lembaga yang peduli dengan BUMDes. Sedangkan Kendala lain yang dialami oleh kedua Mitra antara lain : Pertama dari sisi pengembangan kelembagaan ekonomi desa perlunya perencanaan awal yang tepat dalam menentukan usulan program atau kegiatan khususnya pada kelompok usaha agar mampu meningkatkan pendapatan, pengetahuan dan keterampilan masyarakat melalui pelaksanaan program pelatihan penguatan kelembagaan ekonomi desa. Kedua, dari sisi pengembangan perlunya perencanaan awal dari masyarakat untuk menguatkan lembaga ekenomi di desa dengan berbagai potensi yang dimiliki oleh desa dan masyarakat, serta perlunya sosialisasi pemerintah desa dan instansi terkait dalam rangka menciptakan kekuatan ekonomi baru di desa.

\section{Solusi dan Target Luaran}

Tim pengusul pengabdian pada masyarakat sebagai bagian dari catur darma perguruan tinggi, merasa terpanggil untuk ikut membantu memberikan solusi terhadap permasalahan yang dihadapi oleh kedua Mitra tersebut. Melalui pengabdian pada masyarakat ini dan berdasarkan analisis kebutuhan yang telah dilaksanakan, tim pengabdi mencoba menawarkan solusi terhadap permasalahan tersebut dengan sentuhan Ipteks, yaitu : Penguatan Kelembagaan BUMDes menjadi Kekuatan Baru Ekonomi di Desa, Penyiapan sarana dan prasarana pengembangan potensi desa, Sosialisasi kepada masyarakat, Manajemen pemasaran produk desa. 
Tabel 1.

Target Luaran Pengabdian pada Masyarakat BUMDes

\begin{tabular}{|c|c|c|c|}
\hline No & Produk & Spesifikasi & Target \\
\hline 1. & $\begin{array}{l}\text { Penguatan Kelembagaan } \\
\text { Ekonomi Lokal }\end{array}$ & BUMDes & $\begin{array}{l}\text { Kelompok Usaha } \\
\text { Ekonomi }\end{array}$ \\
\hline 2. & Peminjaman Modal Usaha & Pengurusan Ijin Usaha & $\begin{array}{l}\text { Lembaga } \\
\text { Pengkreditan di } \\
\text { Desa, Koperasi, } \\
\text { Bank Republik } \\
\text { Indonesia dan } \\
\text { Bank lain. }\end{array}$ \\
\hline 3. & $\begin{array}{l}\text { Manajemen pengelolaan } \\
\text { fasilitas tempat usaha }\end{array}$ & $\begin{array}{l}\text { manajemen usaha yang } \\
\text { teratur, budaya tertib } \\
\text { jasa pelayanan } \\
\text { konsumen }\end{array}$ & Potensi desa \\
\hline 4. & $\begin{array}{l}\text { Peningkatan pengetahuan Pengurus } \\
\text { BUMDes bersama tata kelola } \\
\text { BUMDes }\end{array}$ & Pengurus BUMDes & Standarisas mutu \\
\hline 5 . & $\begin{array}{l}\text { Pendampingan, pelatihan } \\
\text { dan workshop }\end{array}$ & Pengurus BUMDes & $\begin{array}{l}\text { Inovasi dan } \\
\text { pemanfaatan } \\
\text { teknologi produksi }\end{array}$ \\
\hline 6. & $\begin{array}{l}\text { Peningkatan pengetahuan tentang } \\
\text { kelestarian lingkungan dan } \\
\text { zona pemanfaatan } \\
\text { kawasan desa }\end{array}$ & $\begin{array}{l}\text { Adanya zonasi } \\
\text { pemanfaatan kawasan } \\
\text { Desa Wajah Jaya dan } \\
\text { Mulia Jaya yang di } \\
\text { sepakati semua } \\
\text { stakeholder }\end{array}$ & $\begin{array}{l}\text { Peta Zonasi } \\
\text { Pemanfaatan } \\
\text { Kawasan } \\
\text { potensi Desa }\end{array}$ \\
\hline 7. & $\begin{array}{l}\text { Peningkatan pengetahuan tentang } \\
\text { manajemen dan produksi desa } \\
\text { wisata berbasis Kolaboratif }\end{array}$ & $\begin{array}{l}\text { Meningkatnya } \\
\text { pemahaman pengurus } \\
\text { BUMDes dan } \\
\text { masyarakat akan } \\
\text { kewirausahaan. }\end{array}$ & $\begin{array}{l}\text { Promosi Potensi } \\
\text { Desa }\end{array}$ \\
\hline
\end{tabular}

Berdasarkan target luaran di atas maka Pengabdian pada Masyarakat ini adalah pendampingan dan pelatihan ini juga berupa artikel ilmiah yang dipublikasikan pada jurnal nasional dan untuk menambah wawasan pengetahuan dan pemahaman bagi Pengurus BUMDes dan Masyarakat berupa pemasaran penjualan produk sampai diluar daerah. Sedangkan target lainnya dapat 
memberikan penguasaan keterampilan bagi kelompok usaha dan kelompok tani agar dapat meningkatkan kualitas, kuantitas, serta nilai tambah barang, jasa, atau sumber daya desa lainnya, Perbaikan arah kebijakan, Peningkatan kondisi sosial ekonomi, perbaikan moral dan karakter, serta Terbangunnya sentra-sentra Ekonomi yang merepresentasikan unggulan/ciri khas masyarakat desa Wajah Jaya dan Desa Mulia Jaya Kecamatan Lasalimu Selatan.

\section{Metode Pelaksanaan}

Metode pendekatan yang ditawarkan untuk menyelesaikan persoalan mitra program yang telah disepakati bersama untuk kedua aspek utama dalam kurun waktu realisasi Pengabdian pada Masyarakat adalah dengan menggunakan metode pelatihan dan pendampingan, secara teknis metode yang digunakan adalah Metode Focus Group Discussion, dan Metode Pendampingan dimana dalam kegiatan ini peserta Mitra Program yaitu BUMDes dan Masyarakat di desa Wajah Jaya dan Mulia Jaya menjadi pelaku utama dalam rangka mencapai tujuan kegiatan pelatihan. Sedangkan dalam implementasi metode dilapangan, masyarakat menjadi pelaku utama dalam merancang dan menganalisis potensi dan persoalan mereka untuk tujuan menciptakan produk-produk inovatif yang akan memberi nilai tambah dan daya saing yang lebih tinggi. 


\section{PENGUATAN KELEMBAGAAN EKONOMI DESA BERBASIS KOLABORATIF}

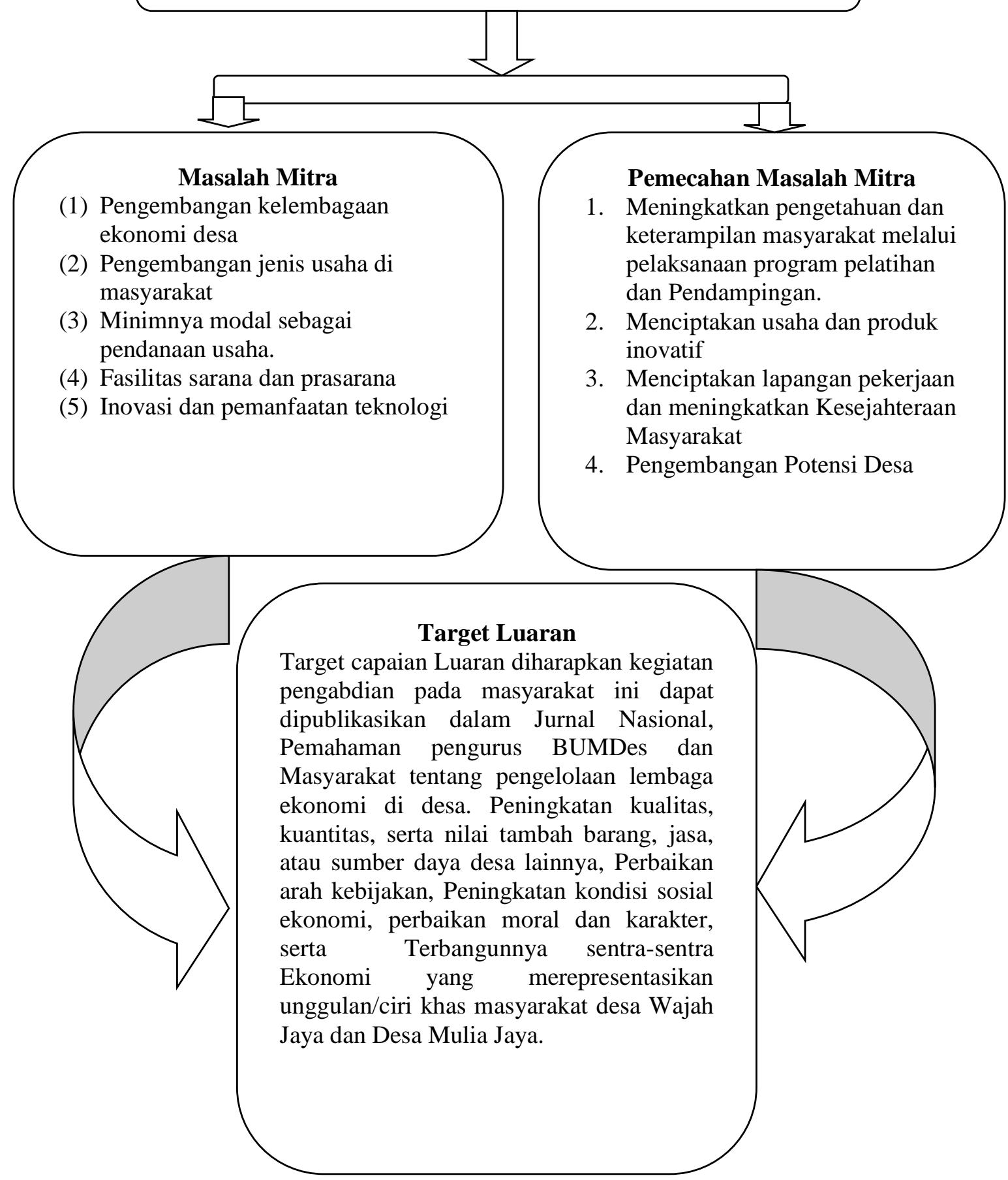




\section{Pembahasan}

\section{Hasil Kegiatan}

Hasil kegiatan yang dilakukan Tim Pengabdi di Desa Mulia Jaya adalah salah satunya pembentukan BUMDes dengan tujuan: 1. Menumbuhkembangkan perekonomian desa; 2. Meningkatkan Sumber Pendapatan Asli Desa; 3. Menyelenggarakan kemanfaatan umum berupa penyediaan jasa bagi peruntukan hajat hidup masyarakat desa; 4. Sebagai perintis bagi kegiatan usaha di desa Sedangkan tujuan pembentukan BUMDes antara lain: 1. Meningkatkan peranan masyarakat desa dalam mengelola sumber-sumber pendapatan lain yang sah; 2 . Menumbuhkembangkan kegiatan ekonomi masyarakat desa, dalam unit-unit usaha desa; 3. Menumbuhkembangkan usaha sektor informal untuk dapat menyerap tenaga kerja masyarakat di desa; 4. Meningkatkan kreatifitas berwira usaha Desa masyarakat desa yang berpenghasilan rendah Pendirian dan pengelolaan Badan Usaha Milik Desa (BUMDes) adalah merupakan perwujudan upaya memaksimalkan peran pengelolaan ekonomi produktif desa yang selama ini dilakukan oleh pemerintah desa. Peran ini perlu dilakukan secara kooperatif, partisipatif, emansipatif, transparansi, akuntabel, dan sustainable agar nantinya pengelolaan BUMDes tersebut dapat berjalan secara efektif, efisien, profesional dan mandiri. Untuk mencapai tujuan BUMDes dilakukan dengan cara memenuhi kebutuhan (produktif dan konsumtif) masyarakat melalui pelayanan distribusi barang dan jasa yang dikelola masyarakat dan Pemdes. Pemenuhan kebutuhan ini diupayakan tidak memberatkan masyarakat, mengingat BUMDes akan menjadi usaha desa yang paling dominan dalam menggerakkan ekonomi desa. Lembaga ini juga dituntut mampu memberikan pelayanan kepada non anggota (di luar desa) dengan menempatkan harga dan pelayanan yang berlaku standar pasar. Artinya terdapat mekanisme kelembagaan/tata aturan yang disepakati bersama, sehingga menimbulkan keseragaman dari usaha-usaha yang dijalankan oleh BUMDes

Pada kunjungan tim pengabdian dari Fakultas Ilmu Sosial dan Ilmu Politik Universitas Muhammadiyah Buton pada tanggal 13-17 Februari 2019 di Desa Wajah Jaya dan dea Mulia Jaya, team pendamping melihat dan mengobservasi 
catatan transaksi Badan Usaha Milik Desa (BUMDes). Dari kegiatan tersebut diketahui bahwa Petugas Badan Usaha Milik Desa (BUMDes) telah melakukan pencatatan secara sederhana meliputi transaksi kas masuk dan kas keluar dengan rinci, namun belum disusun sesuai standar akuntansi untuk jenis usaha jasa. Selanjutnya pada kunjungan kedua, team pendamping membantu Menyusun Neraca Awal pembentukan Badan Usaha Milik Desa (BUMDes), tahun 2019, serta membuat catatan pembelian perlengkapan dan peralatan. Dari hasil kegiatan ini, Petugas Badan Usaha Milik Desa (BUMDes) telah mampu memahami pengertian hata, utang, modal, perlengkapan dan pembelian. Selanjutnya, dari catatan transaksi harian, petugas Badan Usaha Milik Desa (BUMDes) dibantu untuk menyusun laporan laba/rugi untuk tahun 2019. Setelah petugas / karyawan BUMDes mampu menyusun laporan laba/rugi, selanjutnya diarahkan untuk menyusun laporan perubahan modal dan neraca untuk tahun 2019 dengan dipandu tim pendamping, yang telah menyiapkan form laporan keuangan untuk th 2020, dan menyusun buku kerja: Kas masuk, kas Keluar, laba/rugi, perubahan modal dan neraca, untuk tiap bulan. Petugas Badan Usaha Milik Desa (BUMDes) juga sudah praktik membukukan untuk tansaksi Badan Usaha Milik Desa (BUMDes). Setelah melalui serangkaian kegiatan pendampingan yang intensif, pada kunjungan yang tim memeriksa hasil rekapitulasi kas masuk dan keluar serta penyusunan laporan keuangan BUMDes telah mampu melanjutkan pencatatan transaksi hingga penyusunan laporan keuangan. Karyawan Badan Usaha Milik Desa (BUMDes) juga berkonsultasi tentang pekerjaan yang telah dilakukan. Selanjutnya, team pendamping akan tetap melakukan pendampingan apabila diperlukan.

\section{Pembahasan}

Berdasarkan hasil penelusuran tim dosen di lokasi kegiatan PKM, terlihat kebanyakan masyarakat masih kurang memahami tentang BUM Desa, tugas dan fungsinya serta perannya dalam memberdayakan masyarakat bidang ekonomi produktif, sehingga mengakibatkan kurang pedulinya pada upaya mendirikan lembaga BUM Desa, hal inilah yang didapatkan oleh tim dosen selama melakukan penelusuran pendapat masyarakat terkait pemahamannya tentang BUM Desa, 
yang kebanyakan masyarakat bertanya balik kepada kami untuk mengetahui tentang maksud dan tujuan lembaga tersebut. Kurangnya sosialisasi yang dilakukan oleh pemerintah desa menambah permasalahan akan rencana pembentukan BUM Desa padahal lembaga yang bergerak di bidang kewirausahaan ini telah menjadi amanat dari Undang-Undang Nomor 6 Tahun 2014 tentang Desa Pasal 1 Ayat (6) berbunyi : "BUMDesa adalah Badan usaha yang seluruh atau sebagian besar modalnyadimiliki oleh Desa melalui penyertaan secara langsung yang berasal dari kekayaan Desa yang dipisahkan guna mengelola aset, jasa pelayanan, dan usaha lainnya untuk sebesarbesarnyakesejahteraan masyarakat Desa”.

Berdasarkan undang-undang tersebut di atas bahwa BUM Desa sangatlah berperan penting untuk mewujudkan kesejahteraan masyarakat desa melalui pembentukan unit-unit usaha yang dapat mengembangankan potensi-potensi lokal yang dimiliki oleh desa tersebut, dengan pembentukan BUM Desa diharapkan dapat memacu semangat masyarakat desa untuk memaksimalkan pemanfaatan sumber daya yang dimiliki selama ini, misalnya di Desa Mulya Jaya yang kebanyakan penduduknya berprofesi sebagai petani khususnya petani jagung hanya bisa mengandalkan sistem pertanian tradisional dengan memakai alat-alat yang cukup sederhana seperti parang, jangkul, dan beberapa alat-alat pertanian yang mudah dibuat oleh masyarakat lokal sehingga produksi pertaniannya relatif tidak mengalami peningkatan yang signifikan setiap tahunnya, begitupula dengan pemasaran produksi pertanian yang hanya dijual di pasar-pasal lokal seperti Pasar Kecamatan Lasalimu Selatan atau Pasar Kecamatan Pasarwajo, kondisi ini terus berlangsung puluhan tahun sejak masyarakat Desa Mulya Jaya menghuni desa transmigrasi sekitar tahun 1990-an sampai sekarang, bahkan kebanyakan juga hanya bisa untuk memenuhi kebutuhan rumah tangga tanpa mendapatkan penghasilan yang lebih memadai lagi.

Oleh karena lembaga BUM Desa belum terbentuk sehingga sejak tahun 2014 sampai awal 2019 masih fokus pada pembangunan infrastruktur pertanian seperti jalan usaha tani, disisi lain masyarakat belum merasakan langsung dampak ekonomi terutama pada peningkatan pendapatan karena jalan usaha tani yang 
telah dibangun hanya dapat mempermudah jalur transportasi masyarakat untuk melakukan kegiatan bepergian dari satu tempat ke tempat yang lain, seharusnya pembangunan infrastruktur dapat diimbangi dengan pemberian bantuan ekonomi produktif yang langsung menyentuh pada kebutuhan mata pencaharian para petani di Desa Mulya Jaya sehingga dapat memberikan semangat bagi para petani untuk meningkatkan produksi pertaniannya serta menambah penghasilan para petani setiap bulannya.

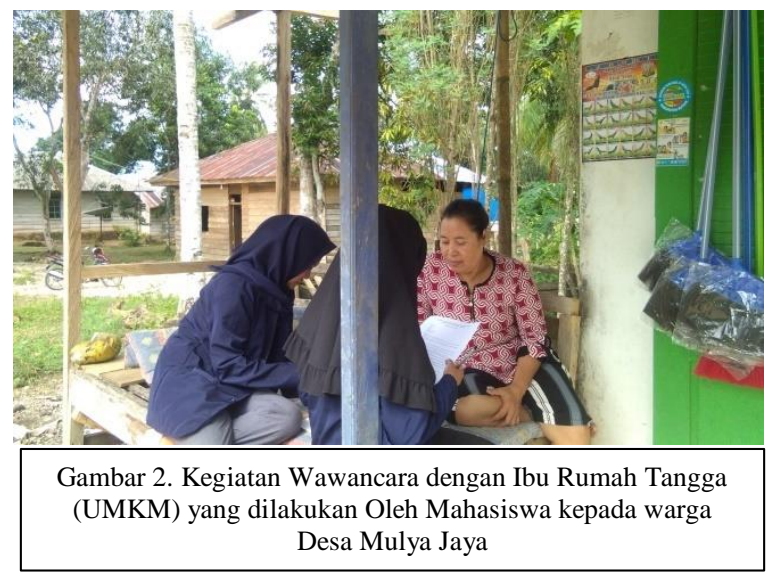

Kehadiran tim dosen beserta mahasiswa yang dilibatkan dalam kegiatan Pengabdian Kepada Masyarakat (PKM) telah membuka pemahaman baru bagi pemerintah desa, BPD maupun masyarakat Desa Mulya Jaya melalui kegiatan identifikasi potensi lokal yang melibatkan mahasiswa Fakultas Ilmu Sosial dan Ilmu Politik untuk melakukan pendataan kepada beberapa warga desa untuk mengetahui tingkat pemahaman warga tentang BUM Desa, dalam kegiatan pendataan tersebut kami menyiapkan pedoman wawancara serta dokumen yang perlu dikumpulkan oleh mahasiswa yang langsung dipimpin oleh dosen Pembina, oleh karena tim dosen dan mahasiswa masih belum menguasai wilayah Desa Mulya Jaya, maka kami bagi masyarakat menjadi 9 tim masing-masing tim beranggotakan 2 orang agar mereka saling membantu dalam pencarian rumah warga dan wawancara terhadap warga setempat.

Selama kegiatan mencari informasi dari warga terkait rencana pembentukan BUM Desa, kebanyakan warga tidak tahu tentang makna BUM Desa dan pentingnya bagi peningkatan ekonomi masyarakat. Hal ini seperti yang dikatakan oleh informan La Ode Nurlian (63 tahun) yang berprofesi sebagai petani di Dusun 1 menyatakan bahwa: 
"saya belum pernah mendengar BUM Desa itu, karena selama ini belum ada lembaga itu di desa" (hasil wawancara tanggal 14 Februari 2019).

Sama halnya yang disampaikan oleh Wa Risma (27 tahun) berprofesi sebagai tenaga guru PAUD di Desa Mulya Jaya mengatakan bahwa:

"saya pernah dengar tahu tidak tahu maksudnya apa itu BUM Desa, karena tidak ada sosialisasi dari pemerintah desa" (hasil wawancara tanggal 14 Februari 2019).

Pernyataan kedua informan di atas mempunyai persamaan yaitu mereka belum tahu maksud dan manfaat BUM Desa bagi masyarakat desa, sementara keberadaan BUM Desa adalah salah satu wadah yang dapat memecahkan masalah masyarakat khususnya bidang ekonomi, hasil pengamatan kami juga selama melakukan kegiatan di Desa Mulya Jaya belum tampak papan informasi tentang BUM Desa, balehonya yang berisi tentang ajakan untuk membentuk dan mendukung BUM Desa, bahkan di kantor desa pun tidak ada pamflet atau pengumuman tentang BUM Desa, maka wajar jikalau warga desa kebanyakan tidak tahu menahu tentang BUM Desa.

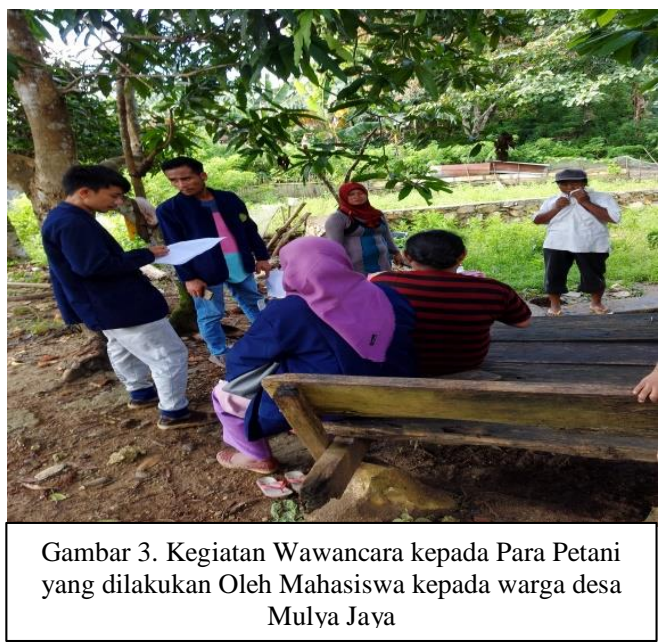

sebagai petani mengatakan bahwa:
Dalam proses kegiatan wawancara dengan warga setempat, kami juga meminta dukungan warga dalam rencana pembentukan BUM Desa di desanya, hasilnya warga desa menyetujui untuk segera membentuk BUM Desa karena dirasakan perlu untuk meningkatkan perekonomian masyarakat desa seperti yang dikatakan oleh informan Ibu Mania (27 tahun) bekerja

"saya sangat mendukung pembentukan BUM Desa karena bisa membantu para petani disini” (hasil wawancara tanggal 14 Februari 2019). Begitupula dengan informan lain Pak Anton (30 tahun) bekerja sebagai petani yang mengatakan: 
"Iya, saya setuju kalau BUM Desa dibentuk di desa ini karena disini kan kebanyakan masyarakat berprofesi sebagai petani pastinya sangat dibutuhkan".(hasil wawancara tanggal 14 Februari 2019).

Berdasarkan beberapa pernyataan informan di atas tentunya menjadi pertimbangan kepada aparatur pemerintah desa Mulya Jaya untuk segera membentuk BUM Desa agar bisa memberikan solusi terhadap permasalahan pertanian seperti pembasmian hama, penyediaan pupuk dan bibit serta penyediaan alat-alat pertanian yang lebih modern agar lebih mempermudah proses kerja para petani dan diharapkan dapat menambah produksi pertanian setiap tahunnya. Antuasias masyarakat desa dibuktikan dengan kesadaran mereka mengikuti kegiatan seminar "Penguatan Kelembagaan BUM Desa" yang diadakan oleh tim dosen Fakultas Ilmu Sosial dan Ilmu Politik pada hari Jum'at malam, tanggal 15 Februari 2019 bertempat di Aula Kantor Desa Mulya Jaya, di dalam kegiatan ini diikuti juga Kepala Desa, Ketua BPD serta perangkat desa lainnya, alhasil pasca kegiatan seminar ternyata memberikan dampak pada pemahaman masyarakat tentang pentingnya di bentuk BUM Desa. Pemerintah desa, BPD dan berbagai elemen masyarakat yang hadir sangat antusias ingin melakukan musyawarah desa dengan harapan dalam menjadi semangat baru bagi masyarakat desa untuk meningkatkan produktivitas pertaniannya dan menambah pendapatan setiap tahunnya. Dengan adanya kegiatan ini pemerintah desa, pengurus BPD dan masyarakat Desa Mulya Jaya berharap agar dapat dilakukan lagi di desanya karena banyak informasi yang disampaikan oleh dosen-dosen serta mahasiswa FISIP Universitas Muhammadiyah Buton sangat berguna bagi pembangunan desanya.

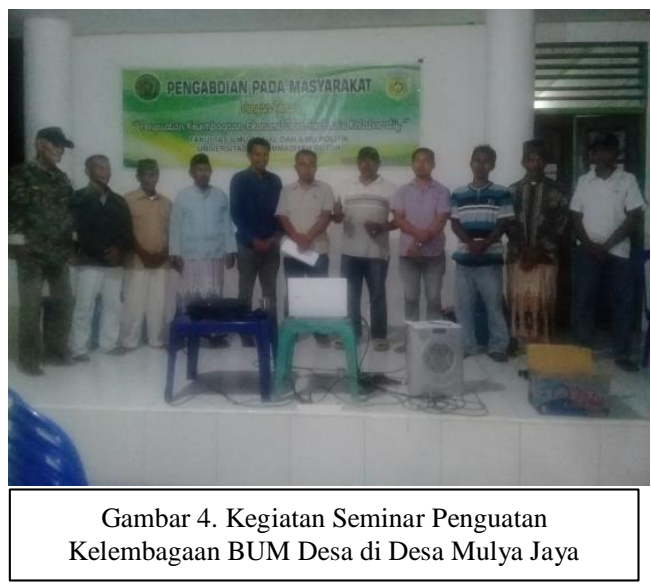

Materi yang ditampilkan disesuaikan dengan kondisi dan potensi yang ada di Desa Mulya Jaya dengan mendayagunaan para petani lokal dengan mengikutkan mereka dalam kepengurusan BUM Desa yang dibentuk dalam unit-unit usaha masing-masing petani, misalnya 
petani jagung harus bisa membentuk satu unit usaha yang bergerak dalam usaha jagung, begitu juga petani padi harus bisa pula membentuk satu unit usaha dalam kegiatan pemberdayaan para petani padi, sama halnya dengan ibuibu yang bergerak di UMKM seperti warung-warung yang menjual sembako dan berbagai kebutuhan rumah tangga harus bisa pula membentuk satu unit usaha agar mendapatkan modal bergulir dari BUM Desa dengan modal yang memadai dan bunga pengembalian yang dapat dijangkau oleh para pelaku usaha mikro dan menengah. Dengan terbentuknya unit-unit usaha yang diketua oleh seorang kepala unit usaha dan semua unit-unit usaha tersebut langsung di pimpin oleh seorang direksi serta kepala desa sebagai ex-officio (penasehat) agar pengelolaan dana desa yang diberikan kepada BUM Desa nanti akan dapat dikelola sesuai dengan aturan perundang-undangan.

Pentingnya pembentukan BUM Desa setidaknya ada tiga manfaat yaitu:

1. Sebagai wadah pelayanan publik artinya BUM Desa yang dibentuk diharapkan dapat meningkatkan pelayanan kepada para petani di Desa Mulya Jaya misalnya pemenuhan kebutuhan puput, bibit, alat-alat pertanian maupun alat penangkal hama yang merupakan tuntutan para petani, yang selama ini masih menjadi kendala dalam usaha pertanian mereka.

2. Mendorong pembangunan desa artinya pendirian BUM Desa diharapkan dapat memberikan kesempatan kepada masyarakat untuk ikutserta dalam menentukan kebutuhan prioritas sesuai dengan potensi desa, dengan berdirinya lembaga yang bergerak di bidang wirausaha ini akan menunjang peningkatan pendapatan para petani dan ibu-ibu yang bergerak di UMKM dengan mengalokasi dana desa sesuai dengan kesepakatan antara pengurus BUM Desa, Pemerintah Desa, BPD beserta masyarakat desa.

3. Meningkatkan kapasitas pemerintah desa menuju desa mandiri artinya BUM Desa dapat memberikan peluang bagi pemerintah desa untuk mewujudkan pendapatan asli desa secara mandiri tanpa mengharapkan banyak bantuan dari pemerintah desa maupun pusat. Seperti halnya desa- 
desa lain yang sudah cukup sukses mengelolaan dana desa hingga dapat menghasilkan miliaran setiap tahunnya, dengan pendapatan asli desa yang memadai tersebut akan dapat membantu sector-sektor lain seperti pemenuhan kebutuhan jaminan kesehatan bagi masyarakat maupun bantuan sosial lainnya bagi masyarakat miskin, maka tugas pemerintah untuk mewujudkan desa mandiri akan lebih cepat terealisasi sesuai dengan harapan masyarakat desa, pemerintah desa dan BPD.

Begitu pula sesuai dengan Peraturan Menteri Desa, Pembangunan Daerah Tertinggal, Dan Transmigrasi Republik Indonesia Nomor 4 Tahun 2019Tentang Pendirian, Pengurusan Dan Pengelolaan, Dan Pembubaran Badan Usaha Milik Desa pasal 3 menyatakan bahwa: "pendirian BUM Desa bertujuan: (a)Meningkatkan perekonomian Desa; (b).Mengoptimalkan aset Desa agar bermanfaat untuk kesejahteraan Desa; (c).Meningkatkan usaha masyarakat dalam pengelolaan potensi ekonomi Desa; (d).Mengembangkan rencana kerja sama usaha antar desa dan/atau dengan pihak ketiga; (e).Menciptakan peluang dan jaringan pasar yang mendukung kebutuhan layanan umum warga; (f).Membuka lapangan kerja; (g).Meningkatkan kesejahteraan masyarakat melalui perbaikan pelayanan umum, pertumbuhan dan pemerataan ekonomi Desa; dan (h).Meningkatkan pendapatan masyarakat Desa dan Pendapatan Asli Desa”.

Berdasarkan pernyataan di atas bahwa upaya mendirikan BUM Desa yang selama ini masih diabaikan oleh pemerintah desa diharapkan dapat memberikan manfaat sesuai dengan amanat peraturan perundang-undangan karena kondisi warga Desa Mulya Jaya banyak berpenghasilan menengah ke bawah dapat diberikan bantuan berupa uang maupun barang yang dapat digunakan untuk meningkatkan usaha masyarakat dalam pengelolaan potensi ekonomi desanya, disamping itu dengan adanya BUM Desa akan membuka lapangan pekerjaan baru bagi warga dengan melibatkannya dalam kepengurusan BUM Desa maupun menjadi bagian dari unit usaha yang bergerak di bidang pertanian maupun UMKM.

Ada beberapa hal yang sangat dibutuhkan dalam menguatkan lembaga BUM Desa yang rencana akan dibentuk di Desa Mulya Jaya yaitu: 
1. Peningkatan pemilikan asset produksi, khususnya tanah perkebunan maupun sawah dan modal keuangan yang menunjang kegiatan operasional BUM Desa, tanah yang dimiliki oleh warga setempat merupakan tanah yang diberikan oleh pemerintah pusat melalui program transmigrasi sejak tahun 1999, dan status tanah kebanyakan sudah bersetifikat yang memberikan kenyamanan dan keamanan bagi warga untuk menggarap tanah miliknya.

2. Peningkatan kualitas sumber daya manusia dengan mengikutkan dalam berbagai pelatihan kelembagaan, pelatihan pengelolaan keuangan dan berbagai pelatihan lainnya yang berhubungan dengan tugasnya dalam meningkatkan produktivitas pertanian maupun menambah pendapatan UMKM.

3. Peningkatan pemanfaatan teknologi tepat guna seperti mesin pemotong padi, alat-alat penyemprot, traktor, ataupun peralatan yang dapat mencegah serangan hama tanaman pertanian.

4. Pembangunan infrastruktur dengan menyediakan infrastruktur dasar seperti pembangunan jalan lingkungan yang sudah dibangun sejak tahun 2019 sampai 2018, pembangunan irigasi untuk mempermudah pengairan, pembangunan bendungan, embung dan lain-lain.

5. Bantuan pemasaran dengan membuka pasar baru ataupun memasarkannya di Pasar Kabupaten Buton, Kota Baubau dan daerah sekitarnya dan pemberianbibit dan pupuk bagi para petani yang setiap tahunnya sering mengalami gagal panen karena pemberian puput yang kurang teratur ataupun penyediaan bibit yang berkualitas.

\section{E. Kesimpulan}

Kesimpulan dalam kegiatan PKM ini adalah sebagai berikut:

1. Masih kurangnya pemahaman masyarakat tentang BUM Desa di Desa Mulya Jaya dikarenakan kurangnya sosialisasi yang dilakukan pemerintah desa sehingga dari tahun 2015 sampai 2018 masih fokus pembangunan fisik tanpa membentuk BUM Desa yang seharusnya sudah lama terbentuk seperti halnya desa-desa lainnya. 
2. Adanya potensi desa yang bisa dikembangkan dengan menggunakan dana desa yaitu lahan pertanian dan perkebunan yang cukup luas serta usaha UMKM yang kebanyakan digeluti oleh perempuan.

3. Dukungan masyarakat, pemerintah desa, dan BPD dalam rencana pembentukan BUM Desa setelah para dosen FISIP Universitas Muhamadiyah Buton melakukan seminar tentang pembentukan dan penguatan lembaga BUM Desa di Desa Mulya Jaya.

4. Adanya kesepatakan bersama untuk menjalin kerjasama antara pihak Fakultas Ilmu Sosial dan Ilmu Politik Universitas Muhammadiyah Buton serta pemerintah Desa Mulya Jaya dalam bentuk MOU (Memorandum of Understanding) agar dapat lebih bersinergis dan berkelanjutan dalam upaya pendidikan, dan pendampingan kepada masyarakat desa. 


\section{DAFTAR PUSTAKA}

Dani Danuar Tri U. 2013. Pengembangan Usaha Mikro Kecil Dan Menengah (UMKM) Berbasis Ekonomi Kreatif Di Kota Semarang. Semarang [ID]. Fakultas Ekonomika Dan Bisnis Universitas Diponegoro. [skripsi]. [internet]. Dapat di unduh dari: http://core.ac.uk/download/pdf/18605482.pdf.

Fajar, Surahman.2012. Administrasi Pemerintahan Desa: Model Penguatan Lembaga Kemasyarakatan Dalam Memperkuat Kemandirian Desa. Jakarta [ID]. Universitas Tarumanegara. [jurnal]. E-Journal Taruma Negara Hal 19. Dapat diunduh dari: http://fia.unira.ac.id/wpcontent/uploads/2012/06/1.-Fajar-Surahman.pdf.

Kuhaja, Tendy. 2014. Kajian Kelembagaan dalam Pengembangan Pariwisata Pantai yang Berkelanjutan. Semarang [ID]. Biro Penerbit Planologi Undip. [jurnal]. Jurnal Pembangunan Wilayah dan Kota Volume 10 (3): 278-292. Dapat di unduh dari http://ejournal.undip.ac.id/index.php/pwk/article/view/7785/6381.

Nasrul, Wedy dkk. 2015. Dukungan Modal Sosial dari Kelembagaan Lokal untuk Melindungi Pasar tradisional Gambir. Padang [ID]. Universitas Andalas. [jurnal]. Menara Ekonomi Vol. I No. 1 (April) : Hal 77-87. Dapat di unduh dari: http://jurnal.lppm-umsb.com/2015/188-dukungan-modal-sosial-darikelembagaan-lokal-untuk-melindungi-pasar-tradisional-gambir-uncariagambir-roxb/

Patiyasa, I Wayan. 2013. Strategi Pengembangan Potensi Desa Menjadi Desa Wisata di Kabupaten Tabanan, Bali. Bali; Sekolah Tinggi Pariwisata Bali Internasional. [e-jurnal]. Vol. 4 No. 1 (Juli-Desember) : Hal 20. Dapat diunduh dari: http://litabmasstpbi.ac.id/ojs/index.php/V41/article/view/85/51.

Pusparini, Hesti. 2011. Strategi Pengembangan Industri Kreatif Di Sumatera Barat (Studi Kasus Industri Kreatif Subsektor Kerajinan: Industri Bordir/Sulaman Dan Pertenunan). Padang [ID]. Dapat diunduh dari:

http://pasca.unand.ac.id/id/wpcontent/uploads/-2011/09/Artikel-Hesti Pusparini_0921206005.pdf.

Sastrayuda. 2010. Konsep Pengembangan Kawasan Desa Wisata. Bandung [ID]. Universitas Pendidikan Indonesia. [jurnal].

Jurnal Info Sosial Ekonomi Vol. 2 No. 1: Hal 6-7. Dapat diunduh dari: http://file.upi.edu/Direktori/FPIPS/LAINNYA/GUMELAR_S/HAND_OU T_MATKUL_KONSEP_RESORT_AND_LEISURE/PENGEMBANGAN _KAWASAN_DESA_WISATA.pdf 